\title{
A Study on the Co-Agglomeration of Manufacturing Industry and Producer Services in Heilongjiang Province
}

\author{
Hongmei Dong ${ }^{1, *}$, and Lili Huang ${ }^{1}$ \\ ${ }^{1}$ Daqing Municipal Party School of CPC, 163313 Daqing, China
}

\begin{abstract}
Manufacturing industry and producer services are two important categories of industrial development in Heilongjiang Province. The co-agglomeration development is conducive to improving the interaction level between them and promoting the development of regional industrial cluster. Based on the relevant data of manufacturing and producer services in Heilongjiang Province, this paper uses the location quotient model to estimate the co-agglomeration of manufacturing and producer services. Heilongjiang Province should promote the integrated development of producer services and manufacturing industry, so as to realize the transformation and upgrading of traditional manufacturing industry in the old industrial base.
\end{abstract}

\section{The introduction}

At present, the service industry has become an important indicator to measure the economic development of a country or region. Judging from the economic structure of developed countries such as Europe and North America, the service industry accounts for more than two-thirds of the GDP and absorbs more than $60 \%$ of the employment. At the same time, under the influence of the rapid development of new technologies such as the information network, the traditional service industry continues to transform and upgrade to the modern service industry, and the development speed and scale of the modern service industry continue to improve, gradually becoming an important driving force for the transformation from "industrial economy" to "service economy". Producer services can produce great external effects, especially the impact on manufacturing is very obvious [1-2]. The manufacturing industry in Heilongjiang Province has a long history of development and a relatively solid foundation. The manufacturing industry is not only an important support for economic development, but also the key to the realization of industrial transformation and upgrading. The coagglomeration of manufacturing industry and producer services plays a positive role in promoting the interactive development of manufacturing industry and producer services, the transformation and upgrading of manufacturing clusters and fostering new growth of regional economy. Heilongjiang Province should further accelerate the deep integration of manufacturing industry and producer services, industrialization and informatization, actively develop service-oriented manufacturing industry, and promote the development of industries to the middle and high-end of the value chain. Using location quotient, this paper analysis the coagglomeration between manufacturing industry and producer services, and give some suggestions to realize the coordinated development of the manufacturing industry and the producer service industry, and form a reasonable industrial spatial layout.

\section{Research methods}

\subsection{Location quotient}

Location quotient can calculate the degree of specialization of a specific industry in a certain region, which is widely used in the analysis of industrial agglomeration. Its calculation formula is as follows:

$$
L Q_{i j}=\frac{L_{i j} / L_{i}}{L_{j} / L}
$$

$L Q_{i j}$ is the location quotient of industry $j$ in region $i$, measured by the number of industry employees. $L_{i j}$ is the number of employees of industry $j$ in region $i . L_{i}$ is the total number of employees in region $i$, and $L_{j}$ is the total number of employees in the industry $\mathrm{j}$. $\mathrm{L}$ is the total number of employees in all industries in China. The value of location quotient is between $(0,+\infty)$. If the location quotient index is greater than 1 , it means that the proportion of industry $j$ in region $i$ is higher than the national average level. Therefore, the industry has a high degree of agglomeration and is the dominant industry in the region.

\subsection{Co-agglomeration}

E-G index constructed by Ellison and Glaeser is commonly used to measure industrial co-agglomeration at present. E-G index greater than 0 means that two industries cluster in the same region; E-G index equal to

\footnotetext{
*Corresponding author: 16266440@qq.com
} 
0 means that two industries do not cluster together in the same region. E-G index less than 0 indicates that the two industries are clustered in different regions respectively [3]. Scholars established a new industrial coagglomeration index on the basis of E-G index[4], and the calculation formula for co-agglomeration between manufacturing industry and producer service is as follows:

$$
C O_{z s}=\left(1-\left|L Q_{z}-L Q_{s}\right| /\left(L Q_{z}+L Q_{s}\right)\right)+\left(L Q_{z}+L Q_{s}\right)
$$

$\mathrm{CO}_{\mathrm{zs}}$ is the co-agglomeration of manufacturing industry and producer services. $L Q_{\mathrm{z}}$ and $L Q_{\mathrm{s}}$ is the location quotient of manufacturing industry and producer services respectively.

\section{Empirical analysis}

\subsection{Data Description}

Relevant studies have not given a clear definition of what producer services are. This paper gives a definition of producer services for transport, storage and post, information transmission, software and information technology, financial intermediation, leasing and business services, scientific research and technical service[5]. The data of the number of employees in manufacturing industry and producer services in Heilongjiang Province and the whole country from 2011

to 2019 are selected, and the data are from the National Bureau of Statistics.

\subsection{Calculation of location quotient}

According to the calculation formula, the location quotient of manufacturing industry and producer services in Heilongjiang Province are shown in Table 1. From 2011 to 2019, the location quotients of manufacturing industry are less than 0.5 , and present a downward trend year by year. It means that the specialized level of manufacturing industry in Heilongjiang is low. The location quotients of transport, storage and post are all greater than 1, and show an obvious increasing trend year by year. It means that the specialized level of manufacturing industry in Heilongjiang is high. The location quotient of information transmission, software and information technology was less than 1, and basically remained stable with a small fluctuation. The location quotient of the financial intermediation was less than 1 before 2012 and more than 1 since 2013, with a very significant upward trend, increasing to 1.391 in 2019 . It means that the specialized level of financial intermediation in Heilongjiang is is constantly improving. Before 2016, the location quotient of leasing and business services was less than 0.6, and since 2017, it has increased significantly. The location quotient of scientific research and technical service is greater than 1 in most years, but it shows a downward trend and has been less than 1 since 2018.

Table 1. Location quotient of manufacturing industry and producer services

\begin{tabular}{|c|c|c|c|c|c|c|}
\hline year & $\begin{array}{c}\text { manufacturing } \\
\text { industry }\end{array}$ & $\begin{array}{c}\text { transport, storage } \\
\text { and post }\end{array}$ & $\begin{array}{c}\text { information transmission, } \\
\text { software and information } \\
\text { technology }\end{array}$ & $\begin{array}{c}\text { financial } \\
\text { intermediation }\end{array}$ & $\begin{array}{c}\text { leasing and } \\
\text { business } \\
\text { services }\end{array}$ & $\begin{array}{c}\text { scientific research } \\
\text { and technical service }\end{array}$ \\
\hline 2011 & 0.497 & 1.194 & 0.885 & 0.900 & 0.539 & 1.266 \\
\hline 2012 & 0.480 & 1.240 & 0.885 & 0.980 & 0.543 & 1.163 \\
\hline 2013 & 0.479 & 1.286 & 0.840 & 1.144 & 0.541 & 1.117 \\
\hline 2014 & 0.474 & 1.304 & 0.917 & 1.210 & 0.560 & 1.143 \\
\hline 2015 & 0.472 & 1.342 & 0.881 & 1.284 & 0.554 & 1.135 \\
\hline 2016 & 0.447 & 1.342 & 0.844 & 1.348 & 0.595 & 1.113 \\
\hline 2017 & 0.421 & 1.367 & 0.887 & 1.408 & 0.653 & 1.088 \\
\hline 2018 & 0.406 & 1.341 & 0.829 & 1.364 & 0.896 & 0.981 \\
\hline 2019 & 0.386 & 1.554 & 0.949 & 1.391 & 1.004 & 0.973 \\
\hline
\end{tabular}

\subsection{Calculation of Co-agglomeration}

According to the calculation formula of coagglomeration, the results of the co-agglomeration between manufacturing industry and producer services in Heilongjiang Province are shown in Table 2. The coagglomeration between manufacturing industry and transport, storage and post has the highest level, with a value of 2.278-2.337, indicating that the development of the two is highly consistent and relatively stable. The coagglomeration between manufacturing industry and information transmission, software and information technology decreased from 2.101 to 1.913 . The coagglomeration between manufacturing industry and financial intermediation increased from 2.108 to 2.210 , indicating the integration between them is gradually improving. The co-agglomeration between manufacturing industry and leasing and business services is less than 2 and basically stable. The co-agglomeration between manufacturing industry and scientific research and technical service decreased from 2.326 to 1.926 . It means that the degree of integration between the two is declining. 
Table 2. Co-agglomeration between manufacturing industry and sectors of the producer service

\begin{tabular}{|c|c|c|c|c|c|}
\hline year & $\begin{array}{c}\text { transport, storage } \\
\text { and post }\end{array}$ & $\begin{array}{c}\text { information transmission, software and } \\
\text { information technology }\end{array}$ & $\begin{array}{c}\text { financial } \\
\text { intermediation }\end{array}$ & $\begin{array}{c}\text { leasing and } \\
\text { business services }\end{array}$ & $\begin{array}{c}\text { scientific research and } \\
\text { technical service }\end{array}$ \\
\hline 2011 & 2.278 & 2.101 & 2.108 & 1.995 & 2.326 \\
\hline 2012 & 2.279 & 2.069 & 2.119 & 1.962 & 2.228 \\
\hline 2013 & 2.307 & 2.045 & 2.212 & 1.958 & 2.196 \\
\hline 2014 & 2.311 & 2.072 & 2.247 & 1.951 & 2.203 \\
\hline 2015 & 2.334 & 2.050 & 2.293 & 1.946 & 2.194 \\
\hline 2016 & 2.289 & 1.984 & 2.294 & 1.901 & 2.133 \\
\hline 2017 & 2.259 & 1.952 & 2.289 & 1.859 & 2.068 \\
\hline 2018 & 2.212 & 1.893 & 2.229 & 1.925 & 1.973 \\
\hline 2019 & 2.337 & 1.913 & 2.210 & 1.945 & 1.926 \\
\hline
\end{tabular}

From the perspective of the overall, the level of coagglomeration between manufacturing and producer services in Heilongjiang Province was above 2 in 2011 and basically remained stable from 2012 to 2015 . Since 2016, the level of co-agglomerationb manufacturing and producer services showed an obvious downward trend and dropped to 1.823 in 2019 . This indicates that the coagglomeration of manufacturing industry and producer services in Heilongjiang Province is weakening, and it is an important task to improve the level of the coagglomeration and realize the mutual promotion between manufacturing industry and producer services.

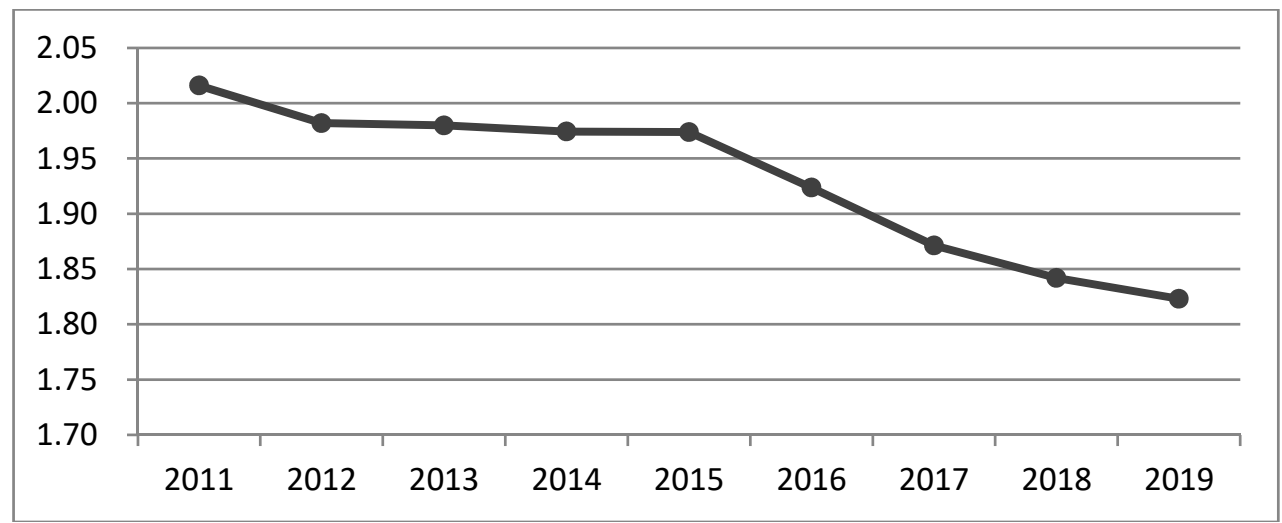

Fig.1. The trend of co-agglomeration between manufacturing industry and producer services

\subsection{Regional distribution of co-agglomeration}

According to the calculation formula of coagglomeration, the co-agglomeration level of manufacturing industry and producer services in cities of Heilongjiang Province is calculated, and the calculation results are shown in Table 3. According to the calculation results, cities in Heilongjiang Province can be divided into two categories according to the coagglomeration level of manufacturing industry and producer services. The first category is the region where the co-agglomeration effect of industry begins to appear, including Harbin, Daqing and Qiqihaer. Harbin, as the capital of Heilongjiang Province, has the highest coagglomeration level of manufacturing industry and producer services, and the co-agglomeration level of all industries is above 2. The co-agglomeration level of manufacturing industry and producer services in Daqing and Qiqihaer is also high. Except for leasing and business services, the co-agglomeration level of other industries is all above 2 . The second category is the other cities outside the above three cities, where the coagglomeration level of manufacturing industry and producer services is low. Only the co-agglomeration between financial intermediation and manufacturing industry in Mudanjiang, Jiamusi, Qitaihe, Heihe and Suihua is above 2. However, for the transport, storage and post, information transmission, software and information technology, leasing and business services, scientific research and technical service, and all producer services, the co-agglomeration between them and manufacturing industry is less than 2 . The results show that theco-agglomeration of manufacturing industry and producer services in Heilongjiang Province presents the characteristics of unbalanced regional distribution. Among all cities, Harbin, Daqing and Qiqihaer are the regions with the highest level of economic development in Heilongjiang Province, with a good foundation of manufacturing industry and a relatively high level of producer services development. Manufacturing industry and producer services are relatively consistent in space, and an industrial development pattern of coagglomeration and benign interaction between the two is gradually forming. The co-agglomeration between manufacturing industry and producer services in the rest of Heilongjiang Province is low, especially in resourcebased cities such as Jixi, Hegang, Shuangyashan, Qitaihe, Heihe and Yichun, industry development is difficult to break through the resource path dependence, coagglomeration between manufacturing industry and 
productive services is very low, and the coordinated development of industry has to be promoted.

Table 3. Co-agglomeration between manufacturing industry and producer services in Cities of Heilongjiang Province

\begin{tabular}{|c|c|c|c|c|c|c|}
\hline city & $\begin{array}{c}\text { transport, } \\
\text { storage and post }\end{array}$ & $\begin{array}{c}\text { information } \\
\text { transmission, } \\
\text { software and } \\
\text { information } \\
\text { technology }\end{array}$ & $\begin{array}{c}\text { financial } \\
\text { intermediation }\end{array}$ & $\begin{array}{c}\text { leasing and } \\
\text { business } \\
\text { services }\end{array}$ & $\begin{array}{c}\text { scientific } \\
\text { research and } \\
\text { technical } \\
\text { service }\end{array}$ & $\begin{array}{c}\text { producer } \\
\text { services }\end{array}$ \\
\hline Haerbin & 3.09 & 2.91 & 2.43 & 3.24 & 2.30 & 2.31 \\
\hline Qiqihaer & 2.22 & 2.21 & 2.49 & 1.83 & 2.14 & 2.34 \\
\hline Mudanjiang & 1.54 & 1.71 & 3.74 & 1.66 & 1.54 & 1.62 \\
\hline Jiamusi & 1.49 & 1.30 & 2.40 & 1.35 & 1.30 & 1.32 \\
\hline Jixi & 1.29 & 1.25 & 1.92 & 1.25 & 1.25 & 1.23 \\
\hline Hegang & 1.10 & 1.09 & 1.12 & 1.98 & 1.23 & 1.08 \\
\hline Shuangyashan & 0.99 & 0.84 & 1.11 & 0.91 & 0.81 & 0.80 \\
\hline Qitaihe & 1.31 & 1.27 & 2.38 & 1.36 & 1.32 & 1.28 \\
\hline Heihe & 1.29 & 0.84 & 2.12 & 0.86 & 0.83 & 0.86 \\
\hline Yichun & 1.44 & 1.44 & 1.43 & 1.37 & 1.44 & 1.45 \\
\hline Daqing & 2.02 & 2.02 & 2.40 & 0.86 & 4.05 & 2.06 \\
\hline Suihua & 1.94 & 1.85 & 2.67 & 1.06 & 1.85 & 1.86 \\
\hline
\end{tabular}

\section{Conclusions}

In 2011-2019, the agglomeration of manufacturing industry in Heilongjiang is relatively low, while the agglomeration of transport, storage and post, financial intermediation, scientific research and technical service is relatively high. The trend of co-agglomeration between manufacturing industry and producer services in Heilongjiang Province shows an obvious downward trend on the whole. Therefore, the following measures can be adopted: Firstly, we should strengthen the development of the manufacturing industry. The manufacturing industry is the most active sector, and is the foundation for the development of producer services. We should increase investment in science and technology and personnel training, focus on cultivating superior industrial sectors in the province, and promote the development level of the manufacturing industry. Secondly, we should strengthen the development of producer services. We should increase investment in science and technology, and improve production efficiency in order to reduce production costs of manufacturing industry. Finally, we should promote the coordination between producer services and manufacturing industry. Based on the good development of manufacturing industry in Heilongjiang Province, we must form a new coordination mechanism between producer service industry and manufacturing industry.

\section{Acknowledgements}

Planning Project of Philosophy and Social Science in Heilongjiang Province" Research on the transformation and upgrading of manufacturing industry in Heilongjiang Province from the perspective of co-agglomeration between producer services and manufacturing industry" (No.20JYE261).

\section{References}

1. Chaoji Y. REFO 6, 13(2018)

2. Yunpeng F, et al. lnunse 3,11(2019)

3. Ellison G, Glaeser L.JPE 105,5(1997)

4. Jianjun C, Jingjing C. CIE 6,14(2011)

5. Manqi J, Qiangmin X. SUN:LKXB 1,18(2014) 